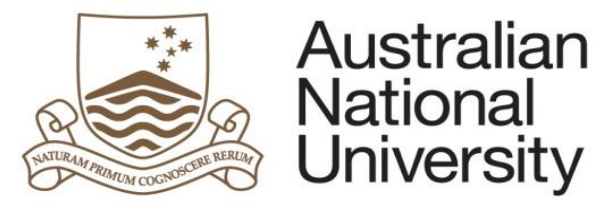

Working Papers in

\title{
Trade and Development
}

\section{A model of global beverage markets}

\author{
Glyn Wittwer
}

Centre of Policy Studies, Victoria University, Melbourne. Australia

Glyn.wittwer@vu.edu.au

and

Kym Anderson

Wine Economics Research Centre, University of Adelaide and Arndt-Corden Department of Economics, Australian National University

Kym.anderson@adelaide.edu.au

February 2020

Working Paper No. 2020/05

\section{Arndt-Corden Department of Economics Crawford School of Public Policy ANU College of Asia and the Pacific}


This Working Paper series provides a vehicle for preliminary circulation of research results in the fields of economic development and international trade. The series is intended to stimulate discussion and critical comment. Staff and visitors in any part of the Australian National University are encouraged to contribute. To facilitate prompt distribution, papers are screened, but not formally refereed.

Copies are available at https://acde.crawford.anu.edu.au/acde-research/working-papers-trade-anddevelopment. 


\title{
A Model of Global Beverage Markets
}

\author{
Glyn Wittwer \\ and \\ Kym Anderson
}

\begin{abstract}
This paper describes a new empirical model of the world's markets for alcoholic beverages and, to illustrate its usefulness, reports results from projections of those markets from 201618 to 2025 under various scenarios. It not only revises and updates a model of the world's wine markets (Wittwer, Berger and Anderson, 2003) but also adds beer and spirits so as to capture the substitutability of those beverages among consumers. The model has some of the features of an economywide computable general equilibrium model, with international trade linking the markets of its 44 countries and seven residual regions. It is used to simulate prospects for these markets by 2025 (business-as-usual), which points to Asia's rise. Then two alternative scenarios to 2025 are explored: one simulates the withdrawal of the United Kingdom from the European Union (EU); the other simulates the effects of the recent imposition of additional $25 \%$ tariffs on selected beverages imported by the United States from several EU member countries. Future applications of the model are discussed in the concluding section.
\end{abstract}

Keywords: CGE modeling; wine; beer; spirits; changes in beverage preferences; international trade in beverages; premiumization of alcohol markets

JEL codes: C53, F11, F17, Q13

Corresponding author:

Professor Kym Anderson

Executive Director, Wine Economics Research Centre

School of Economics, University of Adelaide

Adelaide SA 5005, Australia

Phone +61 883134712

kym.anderson@adelaide.edu.au 


\section{A Model of Global Beverage Markets ${ }^{1}$}

\section{Introduction}

Beverage markets are continuously evolving as technologies and preferences change with population and income growth and as producers, investors, traders and consumers respond also to changes in pertinent policies in their own and other countries. Among the three main alcoholic beverage groups, the traditional concentration of each nation's consumers on one of them (wine, beer or spirits) has been reducing gradually in recent decades. This has contributed to a convergence across countries toward the global average mix of alcoholic consumption, and an increase in the share of global production of each beverage that is traded internationally (Anderson, Meloni and Swinnen, 2018). Since the beverage facing the lowest consumer tax in each country traditionally was the dominant one, a move toward a more uniform tax per unit of alcohol in any country would add to that convergence tendency. Analysis of such market developments and possible policy reforms requires a global economic model in which the interactions between each nation's producers and consumers of these three beverages are explicitly recognized. The purpose of this paper is to provide such a model, calibrate it to 201618 data, and illustrate its usefulness by projecting its myriad markets to 2025 under various scenarios.

Projecting changes in such markets is a fraught business. Yet many participants in these markets need to do this intuitively all the time. This model does not provide predictions of what will happen, but rather a business-as-usual scenario as a baseline against which to compare alternative scenarios that one might envisage.

The paper begins in Section 2 by summarizing the new model of global beverage markets that builds on an earlier model of global wine markets. Section 3 summarizes the sources of data in the model's baseline dataset, which is calibrated to 2016-18. Section 4 draws on past trends in beverage markets to simulate prospects for these markets by 2025 as projected by the model over those eight years (our business-as-usual scenario). Sections 5 and 6 then explore alternative scenarios to 2025. Section 5 simulates the withdrawal of the United Kingdom from the European Union (Brexit) to see how that is likely to affect the business-asusual projection of the world's beverage markets by 2025. Section 6 simulates the effects of the recent imposition of additional $25 \%$ tariffs on selected beverages imported by the United States from the European Union. The concluding section points to further potential applications of this model, most obviously in the area of changes to consumer taxes on beverages.

\section{Structure of the global beverage model}

GLOBAL-BEV is a multi-product model that builds on a model of the world's wine markets (Wittwer, Berger and Anderson, 2003). Its theory is based on that of an economy-wide computable general equilibrium (CGE) model in the ORANI school (Dixon et al., 1982). The equations resemble a hybrid of the TERM (Horridge, 2012) and GTAP (Hertel, 1997) CGE models. The model is implemented using GEMPACK software (Harrison et al., 2014). This 
section presents the equations in levels format and TABLO coding of the model's equations. Within GEMPACK, most equations are presented in a linearized form. Multi-step solution methods (Dixon et al., 1982, chapter 5) enable the modeler to combine the accuracy of the levels form with the relative simplicity and computational speed of linearized equations.

Within the model, wine markets have been disaggregated into four types, namely nonpremium (including bulk), commercial-premium, and super-premium still wines, plus sparkling wine. Commercial-premium still wines are defined by Anderson, Nelgen and Pinilla (2017) to be those between US $\$ 2.50$ and $\$ 7.50$ per litre pre-tax at a country's border or wholesale. Beer and spirits are not split into regular and craft categories, because the latter still have small (albeit growing) market shares in volume terms. The world is divided into 44 individual nations and 7 composite regions.

\subsection{Production}

Each industry uses a combination of intermediate and primary inputs to produce a unit of output. Producer decisions consist of a sequence of constant elasticity of substitution (CES) decisions, with a composite good entering the next stage. Figure 1 shows the production structure.

Figure 1. Production structure of the GLOBAL-BEV model

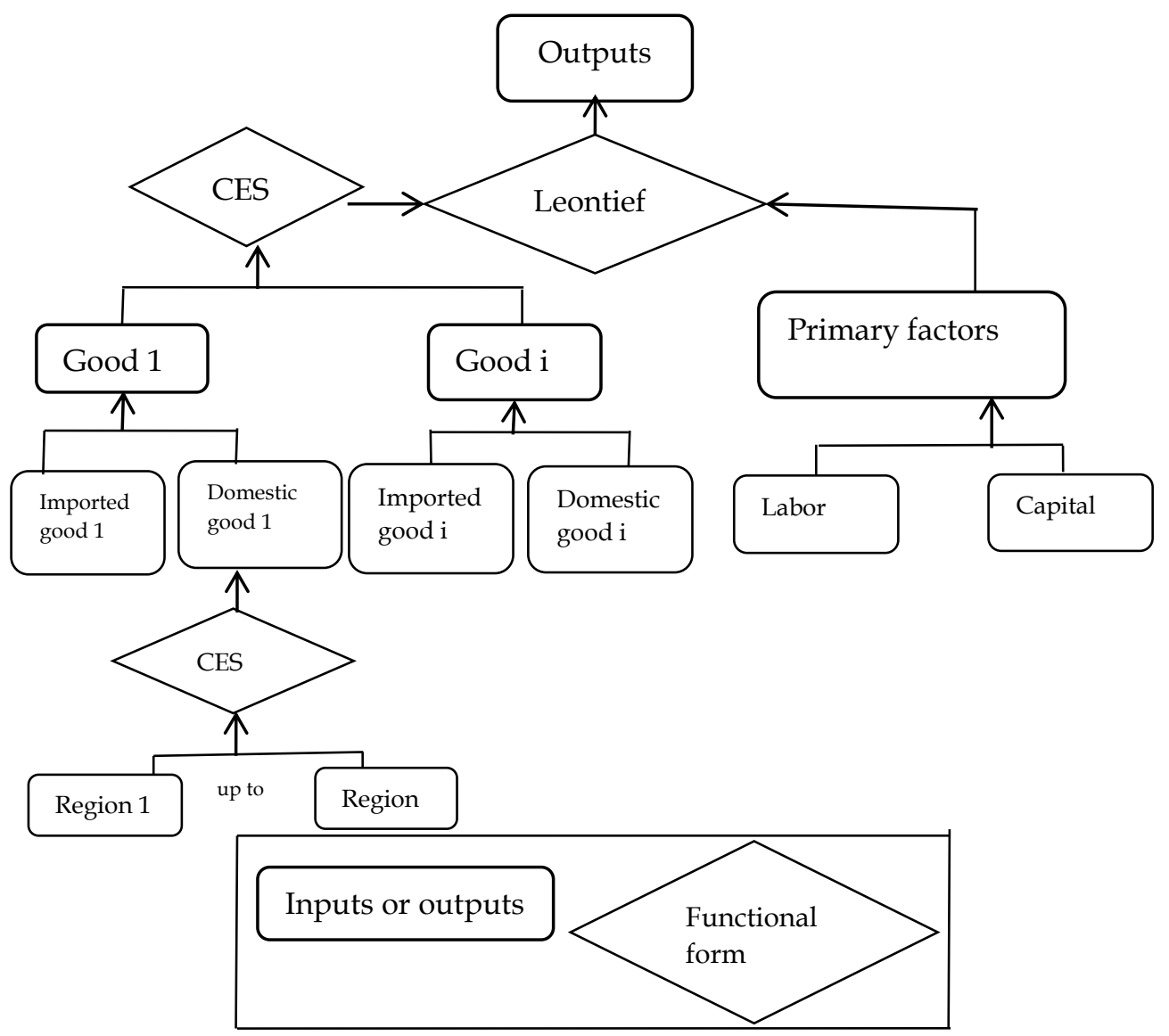

Users of commodities minimize costs subject to CES substitutability:

$$
X_{u r}^{c s}=f\left(X 1_{u r}^{c}, C E S\left[P_{u r}^{c s} / P 1_{u r}^{c}\right]\right)
$$




$$
P 1_{u r}^{c} \cdot X 1_{u r}^{c}=\sum_{s} X_{u r}^{c s} \cdot P_{u r}^{c s}
$$

$X_{u r}^{c s}$ is the quantity demand of commodity $c$ from (domestic composite or imported) source $s$ by user $u$ (both intermediate and final) in region $r$. Users include industries plus a final user, households, in each region. $P_{u r}^{c s}$ is the corresponding price, and $X 1_{u r}^{c}$ and $P 1_{u r}^{c}$ the respective domestic-import composite quantities and prices. Some intermediate inputs such as grapes have endogenous supplies, while others, for whom sales to beverages are a small proportion of total sales, are exogenous implying infinitely elastic supplies.

Table 1: Definitions of variables, values and parameters in production in the GLOBAL-BEV model

\begin{tabular}{|c|c|}
\hline \multirow{2}{*}{\multicolumn{2}{|c|}{ Variables }} \\
\hline & \\
\hline $\operatorname{xint}(c, s, i, r)$ & Source-specific (dom./imp.) intermediate demands \\
\hline xint_s(c,i,r) & Source-composite intermediate demands \\
\hline xhou $(c, s, r)$ & Source-specific (dom./imp.) household demands \\
\hline xhou_s(c,d) & Source-composite household demands \\
\hline $\operatorname{ppur}(\mathrm{c}, \mathrm{s}, \mathrm{i}, \mathrm{r})$ & Source-specific (dom./imp.) tax-inclusive com. price for user \\
\hline ppur_s(c,i,r) & Source-composite tax-inclusive commodity price for user \\
\hline$(\mathrm{c}, \mathrm{s}, \mathrm{u}, \mathrm{r})$ & Source-specific (dom./imp.) commodity price for user \\
\hline tuser $(\mathrm{c}, \mathrm{s}, \mathrm{u}, \mathrm{r})$ & Powers of commodity taxes \\
\hline $\operatorname{pint}(\mathrm{i}, \mathrm{r})$ & Intermediate effective price indices \\
\hline phou $(\mathrm{c}, \mathrm{s}, \mathrm{r})$ & Household price \\
\hline aint_s(c,i,r) & Intermediate tech change \\
\hline xlab(i,r) & Labour demands \\
\hline plab(i,r) & Wage rates \\
\hline xcap $(\mathrm{i}, \mathrm{r})$ & Capital usage \\
\hline $\operatorname{pcap}(\mathrm{i}, \mathrm{r})$ & Rental price of capital \\
\hline $\operatorname{xprim}(\mathrm{i}, \mathrm{r})$ & Primary factor composite \\
\hline $\operatorname{pprim}(\mathrm{i}, \mathrm{r})$ & Effective price of primary factor composite \\
\hline$x \operatorname{tot}(\mathrm{i}, \mathrm{r})$ & Industry outputs \\
\hline atot(i,r) & All-input-augmenting technical change \\
\hline $\operatorname{pcst}(\mathrm{i}, \mathrm{r})$ & Industry output price \\
\hline \multicolumn{2}{|c|}{ Values, shares and parameters } \\
\hline PUR_S(c,i,r) & Purchasers' values summed over sources \\
\hline PUR_CS(i,r) & Purchasers' expenditure summed over commodities \\
\hline SIGMAD (c) & CES parameter, domestic v. import sources \\
\hline $\mathrm{LAB}(\mathrm{i}, \mathrm{r})$ & Wage bill \\
\hline $\mathrm{CAP}(\mathrm{i}, \mathrm{r})$ & Rentals to capital \\
\hline $\mathrm{LND}(\mathrm{i}, \mathrm{r})$ & Rentals to land \\
\hline $\operatorname{PRIM}(i, r)$ & Total factor input to industry i \\
\hline SIGMAPRIM(i) & CES parameter, primary factors \\
\hline $\operatorname{SRCSHR}(\mathrm{c}, \mathrm{s}, \mathrm{u}, \mathrm{r})$ & Imp/dom shares \\
\hline
\end{tabular}

Throughout the TABLO notation in this section, the index c refers to commodities $(\mathrm{COM}), \mathrm{s}$ to domestic or imported source (SRC), $\mathrm{r}$ to regional destination (REG), $\mathrm{u}$ to users (USR) and i to industry (IND $\in$ USR).

Next, we outline cost-minimizing behavior in primary factor demands by industry users. 


$$
\begin{aligned}
& L_{i r}=f\left(F_{i r}, C E S\left[W_{i r} / P F_{i r}\right]\right) \\
& K_{i r}=f\left(F_{i r}, C E S\left(R_{i r} / P F_{i r}\right]\right) \\
& P F_{i r} \cdot F_{i r}=L_{i r} \cdot W_{i r}+K_{i r} \cdot R_{i r}
\end{aligned}
$$

Equations (3) to (5) show primary factor demands for labour $L_{i r}$ and capital $K_{i r}$, subject to a composite factor demand $F_{i r}$ by industry $i$ in region $r$. The factor prices are $W_{i r}$ for labour, $R_{i r}$ for capital rentals and $P F_{i r}$ for composite prices.

The composite factor demand $F_{i r}$ is proportional to total output $Q_{i r}$ subject to a primary-factor using technology $A_{i r}$.

$$
F_{i r}=Q_{i r} \cdot A_{i r}
$$

The demand $X 1_{i r}^{c}$ is related to output $Q_{i r}$ by a CES relationship between the composite price $P 1_{i r}^{c}$ and the price composite of all intermediate goods $P 11_{i r}$ via a CES function.

$$
\begin{gathered}
X 1_{i r}^{c}=f\left(Q_{i r}, C E S\left[P 1_{i r}^{c} / P 11_{i r}\right]\right) \\
P 11_{i r} . X 11_{i r}=\sum_{c} P_{i r}^{c} \cdot X 1_{i r}^{c}
\end{gathered}
$$

The zero pure profit condition is that total revenue, valued at the output price net of production taxes, $P C_{i r}$, multiplied by $Q_{i r}$ equals the total production cost.

$$
P C_{i r} \cdot Q_{i r}=\sum_{c} P_{i r}^{c} \cdot X 1_{i r}^{c}+W_{i r} L_{i r}+R_{i r} \cdot K_{i r}
$$

Listing 1 shows the percentage change quantity equations concerning equations (1) to (9) in TABLO format. ${ }^{1}$ The index "hou" refers to the household element of the user set.

Listing 1. Production (partial GEMPACK coding) in the GLOBAL-BEV model

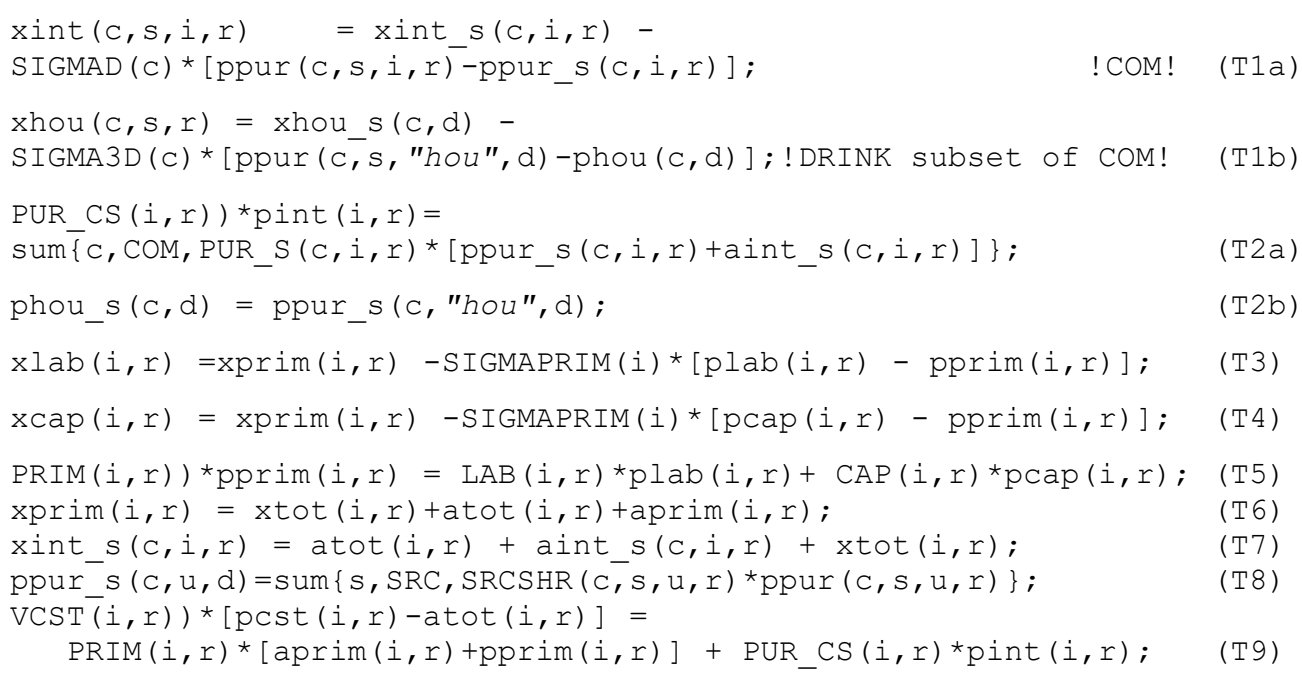

${ }^{1}$ Note that the TABLO equation numbering follows that of previous equations in the text: that is, (T7) corresponds with (7). 


\subsection{Commodity sourcing of demands}

Consumers in a given region source from other regions in common proportions, so that the user subscript is dropped from the equation for CES substitution between import origins:

$$
\begin{array}{ll}
X T_{o r}^{c}=f\left(X T 1_{r}^{c, " i m p "}, C E S\left[P D_{o r}^{c} / P U_{r}^{c, " \text { imp }}\right]\right. & \\
P U_{\text {"imp }, r}^{c} \cdot X T 1_{r}^{c, " i m p "}=\sum_{o} X T_{o r}^{c} . P D_{o r}^{c} & \\
P_{L O C s r}^{c}=P_{s r}^{c} \cdot \phi_{r} / \phi_{o} & \\
P D_{o r}^{c}=P_{o r}^{c} \cdot P_{G D P}^{o} / P_{G D P}^{r} & \text { (RawMat } \in \text { Com) } \\
P D_{o r}^{c}=P_{G D P}^{o} / P_{G D P}^{r} \cdot F^{c o} & \text { (MatInp } \in \text { Com) } \\
P D_{o r}^{c}=P_{o r}^{c}+\sum_{m} P_{r}^{m} & \text { (Drink } \in \text { Com) } \\
P_{r}^{m}=F_{r}^{m} \cdot P_{G D P}^{r} & \text { (Mar } \in \text { Com) }
\end{array}
$$

The total demand for all users of commodity $c$, domestic or import source $s$, from import origin $o$ to destination $d$ is $X T_{o d}^{c, " i m p "}$. Composite import demands are denoted by $X T 1_{d}^{c, " i m p " ~ a n d ~ u s e r ~ p r i c e s ~ b y ~} P U_{d}^{c, " i m p "}$. The delivered price from origin $o$ to destination $r$ is $P D_{o r}^{c}$ . GLOBAL-BEV substitutability possibilities involve two stages, between import origins to form the import composite and between the domestic source and import composite.

In the partial equilibrium implementation, there are three subsets within COM. The set MatInp consists of intermediate inputs whose supplies are exogenous. This assumes that changes in beverage input demands have no impacts on the market for these inputs. We need to make judgments as to which food inputs should be endogenous. Grape prices will move with changes in global wine market conditions, as a large share of the global grape crop is crushed to produce wine. Moreover, winegrape varieties differ from table grapes. Grapes are in the RawMat subset of COM. Should grains be exogenous? Barley and wheat used in the manufacture of beverages may account for a significant fraction of local production in some regions, less so nationally. However, we could impose an exogenous shift in supply to depict, for example, a government food policy to divert grains away from beverages towards food production. In a modelling context, this would result in beverage manufacturers switching towards imported grains in response to such a domestic policy.

It would be a simple task to allocate various grains to the RawMat subset but, in this implementation of the model, grains are in the MatInp subset of exogenously supplied inputs. Delivered prices for the three subsets of COM (MatInp, RawMat and Drink) are solved in three distinct groups of equations in GLOBAL-BEV in equations (13) to (15).

GLOBAL-BEV includes nominal exchange rates relative to the US dollar (the numeraire). Changes in a nation's nominal exchange rate will only affect a producer's competitiveness in the global beverage market if it is transmitted through to real impacts. If a movement in the general price level and in nominal wages exactly offset a nominal exchange rate movement, there is no change in a nation's international competitiveness. We would expect real exchange movements to be reflected in changes in wages and the GDP deflator in a given country relative to the United States, which are exogenous in this partial equilibrium model. The RawMat subset's delivered price is the endogenous basic price $P_{o r}^{c}$ adjusted for GDP deflator movements. The Drink subset delivered price consists of the basic price plus margins. 
Table 2. Definitions of variables, values and parameters in trade in the GLOBAL-BEV model

\begin{tabular}{ll}
\hline $\begin{array}{l}\text { Variables } \\
\text { xuse }(\mathrm{c}, \mathrm{s}, \mathrm{r})\end{array}$ & Total demand for regional dom/imp \\
xtrad $(\mathrm{c}, \mathrm{r}, \mathrm{d})$ & Quantity of commodity imported from origin $\mathrm{r}$ to destination d \\
xtradd $(\mathrm{c}, \mathrm{r})$ & Home supplied demands \\
pdelivrdt $(\mathrm{c}, \mathrm{s}, \mathrm{r})$ & All-user delivered price of good $\mathrm{c}, \mathrm{s} \neq \mathrm{r}$ \\
$\operatorname{pdelivrdh}(\mathrm{c}, \mathrm{s})$ & All-user delivered price of good $\mathrm{c}, \mathrm{s}=\mathrm{r}$ \\
$\operatorname{pgdp}(\mathrm{s})$ & GDP price \\
p_mar $(\mathrm{m})$ & Price of margins \\
fp_mar $(\mathrm{m}, \mathrm{r})$ & Shifter in price of margins \\
Values and parameters & \\
BASSHRT $(\mathrm{c}, \mathrm{s}, \mathrm{r})$ & Basic value share of user price \\
MARSHRT $(\mathrm{c}, \mathrm{m}, \mathrm{s}, \mathrm{d})$ & Margins value share of user price \\
$\operatorname{DELIVRDT}(\mathrm{c}, \mathrm{s}, \mathrm{r})$ & Trade plus margins = delivered values \\
$\operatorname{SIGMA3M}(\mathrm{c})$ & CES parameter for substitution between import origins \\
\hline
\end{tabular}

Listing 2. International trade (partial GEMPACK coding) in the GLOBAL-BEV model

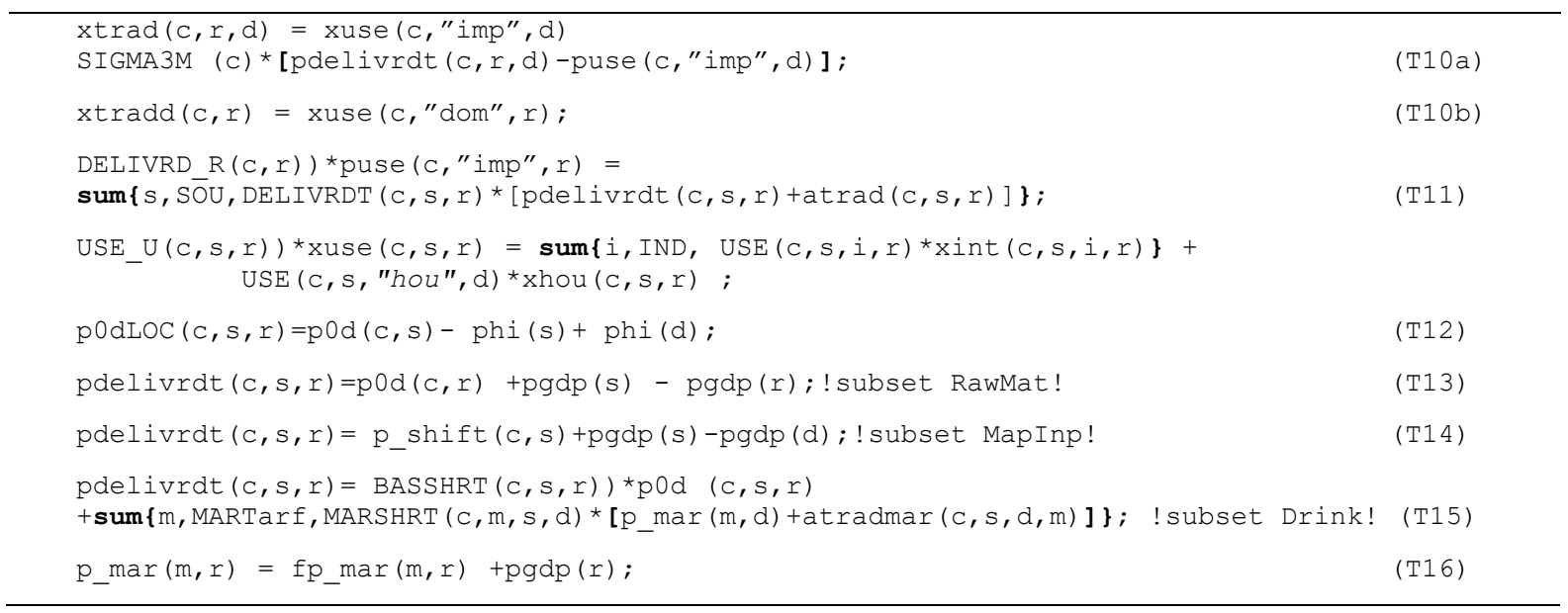

\subsection{Household demands}

The linear expenditure system (LES) is based on a utility function $(U)$ which splits household spending on each commodity $\left(X_{H} H_{c}\right)$ into two, a subsistence component $X_{S U} B_{c}$ that depends only on the number of households $(N)$ and preferences, and a luxury component, $\mathrm{XLUX}_{c}$ that depends on prices and income in a Cobb-Douglas form. $\beta_{c}$ is the marginal budget (i.e., aggregate spending minus aggregate subsistence spending) share of commodity c. The regional dimensions is omitted from equations (17) to (28). The sectors in the household demand system are in the set $\mathrm{ComH}$, which includes the set Drink plus a single sector covering all other household expenditure.

$$
U=\frac{1}{N_{c}} \prod_{c}\left(X H O U_{c}-X S U B_{c}\right)^{\beta_{c}}
$$

Aggregate spending $(W H O U)$ is of the form:

$$
W H O U=\sum_{c} P 3_{c} X H O U_{c}=\sum_{c} P 3_{c} X S U B_{c}+\left[W H O U-\sum_{c} P 3_{c} X S U B_{c}\right]
$$


From this, we obtain the linear expenditure function, where $P 3_{c}$ is the price faced by household consumers of commodity $c$ :

$$
P 3_{c} X H O U_{c}=P 3_{c} X S U B_{c}+\beta_{c}\left[W H O U-\sum_{d} P 3_{d} X S U B_{d}\right]
$$

Aggregate subsistence expenditure WSUB is given by:

$$
W S U B=\sum_{c} P 3_{c} . X S U B_{c}
$$

The Frisch "parameter" is the (negative) ratio of total expenditure to luxury expenditure:

$$
\text { Frisch }=- \text { WHOU/[WHOU }- \text { WSUB] }
$$

The ORANI school (Dixon et al., 1982) typically assigns a Frisch "parameter" of -1.82 to a model for a relatively high income nation.

Differentiating equation (19) with respect to $W H O U$, and multiplying by $\mathrm{WHOU} /\left[\mathrm{XHOU}_{c} \cdot P 3_{c}\right]$, we calculate the expenditure elasticity $E P S_{c}$. This is equal to the marginal budget share divided by the budget share $\left(\mathrm{SHOU}_{c}=\mathrm{P}_{c} . \mathrm{XHOU} \mathrm{U}_{c} \mathrm{WHOU}\right)$ for each commodity:

$$
\mathrm{EPS}_{c}=\beta_{c} \cdot \mathrm{WHOU} /\left[\mathrm{P3}_{c} \cdot \mathrm{XHOU}_{c}\right]
$$

$B L U X_{c}$ is the ratio of luxury expenditure to total expenditure on each commodity, given by:

$$
B L U X_{c}=\beta_{c}[W H O U-W S U B] /\left[P 3_{c} \cdot X H O U_{c}\right]
$$

Substituting equations (21) and (22) into equation (23):

$$
B L U X_{c}=-E P S_{c} / \text { Frisch }
$$

Next, we calculate the matrix of price elasticities implied by LES. By differentiating equation (19) with respect to $P 3_{d}$ [i.e., $d X H O U_{c} / d P 3_{d}=-\beta_{c} X S U B_{d} / P 3_{c}$ ], we calculate the offdiagonal elements of the price elasticity matrix $\left(\eta_{c d}\right)$ :

$$
\begin{aligned}
& d X H O U_{c} / d P 3_{d} \cdot\left[P 3_{d} / X_{H O U}\right]= \\
& -\beta_{c .}(W H O U)\left(P 3_{d} X S U B_{d}\right) /\left(W H O U . P 3_{c}\right) .\left[P 3_{d} / X H O U_{c}\right] \\
& \eta_{c d}=\beta_{c}\left(1-B L U X_{d}\right) . S H O U_{d} / S_{H O U}
\end{aligned}
$$

We obtain the diagonal elements by dividing equation (22) by $P 3_{c}$ and differentiating with respect to $P 3_{c}$ :

$$
\begin{array}{r}
d X \mathrm{HOU}_{c} / d P 3_{c .}\left[P 3_{c} / \mathrm{XHOU}_{c}\right]=-\beta_{c} W H O U /\left[P 3_{c} . X H O U_{c}\right]+ \\
\Sigma \beta_{c}(\mathrm{WHOU}) P 3_{d . X S U B} /\left[\left(\mathrm{WHOU} . P 3_{c}\right) .\left[P 3_{c . X H O U}\right]\right.
\end{array}
$$

Substituting equations (22) and (26) into equation (27), we obtain:

$$
\eta_{c c}=-E P S_{c}-\sum_{d \neq c} \eta_{c d}
$$

LES does not allow for specific substitutability. Where appropriate, specific substitutes could form a CES nest, with the CES composite commodity entering LES within the model. In addition, LES does not allow for goods with negative income elasticities. 
Table 3. Definitions of variables and shares in GLOBAL-BEV's household demand system

\begin{tabular}{|c|c|}
\hline \multicolumn{2}{|l|}{ Variables } \\
\hline xhou_s(c,d) & Household demands \\
\hline wlux $(d)$ & Total nominal supernumerary household expenditure \\
\hline xhoutot(d) & Total real household consumption \\
\hline whoutot(d) & Total nominal household consumption \\
\hline phoutot(d) & CPI \\
\hline nhou(d) & Number of households \\
\hline $\operatorname{xlux}(\mathrm{c}, \mathrm{d})$ & Household - supernumerary demands \\
\hline xsub(c,d) & Household - subsistence demands \\
\hline $\operatorname{alux}(\mathrm{c}, \mathrm{d})$ & Taste change, supernumerary demands \\
\hline $\operatorname{asub}(\mathrm{c}, \mathrm{d})$ & Taste change, subsistence demands \\
\hline ahou_s(c,d) & Taste change,household imp/dom compsite \\
\hline \multicolumn{2}{|c|}{ Values and shares } \\
\hline $\operatorname{BLUX}(\mathrm{c}, \mathrm{d})$ & Luxury share of expenditure on commodity c \\
\hline BUDGSHR(c,d) & Budget share \\
\hline $\operatorname{SLUX}(\mathrm{c}, \mathrm{d})$ & Marginal budget share \\
\hline
\end{tabular}

Rather than include the general household demand equation in the model with the elasticities implied by equations (26) and (28), the LES in GLOBAL-BEV is coded as shown in Listing 3.

Anderson et al. (2011) modelled scenarios in which Australia switched from an ad valorem to a volumetric tax on wine. This may induce substitution away from wines with low unit values towards wines with higher unit values. The study introduced specific substitution by including a single wine nest in the LES demand system, with CES substitution between different types of wine. The nested wine type would have a single expenditure elasticity.

The CES form is used in two contexts concerning household demand. First, if we wish to have specific substitutability between different beverages, we move the subset of beverages out of the LES form and replace with a CES composite. For example, if fine wine and commercial premium wine are substitutable, a CES composite bottled wine may enter the CES nest:

$$
X H O U 2_{c 1}=f\left(X H O U_{c}, C E S\left[P D_{c 1} / P 3_{c}\right]\right.
$$

In (29), subscript $c 1$ refers to the specific beverages and $c$ the CES composite bottled wine.

The second CES context for households (a subset of users) concerns substitutability by source, in equation (10).

One simplifying advantage of the partial equilibrium form of GLOBAL-BEV is that additional commodities can be added to the Drink set without altering the existing inputoutput data. GLOBAL-BEV started with grapes in the RawMat set and wines in the Drink set. In expanding the Drink set, the only modification required to the existing database apart from enlarging the various sales and costs matrices is to subtract the household expenditures of 
new beverages from the initial sector covering spending on goods and services other than Drink. $^{2}$

Listing 3. Household demand (partial GEMPACK coding) in the GLOBAL-BEV model

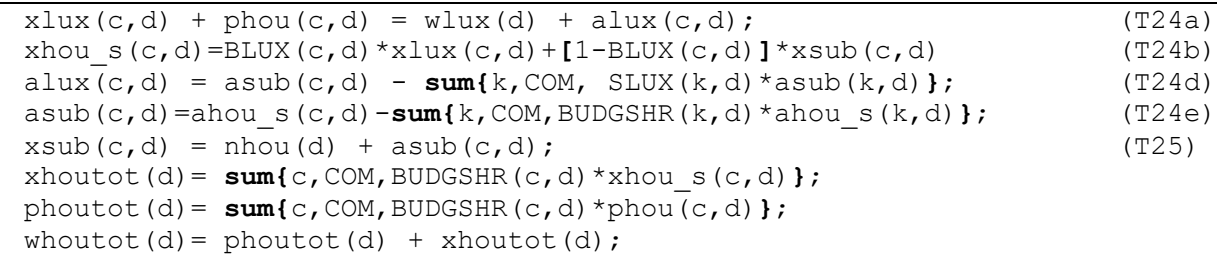

2.4 Margins, market clearing, macro and tax collection equations

GLOBAL-BEV separates the market for margins from the market for commodities being delivered by margins $m$ (Dixon et al., 1982). Demands for margins $X T M_{r d}^{c s m}$ are proportional to commodity demands $X T_{r d}^{c s}$ subject to a margins-using technology $A T M_{r d}^{c s m}$ (equation (30)).

$$
X T M_{r d}^{c s m}=A T M_{r d}^{c s m} \cdot X T_{r d}^{c s}
$$

In equation (31), $P B A S_{r}^{c s}$ is the basic commodity price and $P M_{r d}^{m}$ the margins' prices. $P U_{d}^{c s}$ is the margins-inclusive, tax-exclusive source-composite delivered price that appears in equation (15).

$$
P D_{r d}^{c s} \cdot X T_{r d}^{c s}=P B A S_{r}^{c s} \cdot X T_{r d}^{c s}+\sum_{m} P M_{r d}^{m} \cdot X T M_{r d}^{c s m}
$$

Equation (32) is the market clearing condition for industry outputs. Additional market clearing equations are required due to the common sourcing assumption. Equation (33) links commodity sales summed across destinations to regional supplies.

$$
\begin{aligned}
& P T O T_{i d} \cdot Q_{i d}-X S T_{i d}=\sum_{c} M Q_{c i d} \\
& \sum_{u} X_{u d}^{c s} \cdot P_{u d}^{c s}=P U_{s d}^{c} \cdot X T 1_{d}^{c s}
\end{aligned}
$$

Wages $\left(W_{r}\right)$ by region are linked either to the consumer price index $\left(C P I_{r}\right)$ or the GDP deflator $\left(P_{G D P}^{r}\right)$ via a binary variable $B$.

$$
\begin{aligned}
& W_{r}=F W_{r}\left[B \cdot P_{G D P}^{r}+(1-B) \cdot C P I_{r}\right] \\
& W_{i r}=W_{r}
\end{aligned}
$$

The real exchange rate $\left(R E X C_{r}\right)$ in each nation relative to the US dollar is given by:

$$
R E X C_{r}=P_{G D P}^{r} /\left[P_{G D P}^{\| U S} \cdot \phi_{r}\right]
$$

\footnotetext{
2 The sole exception in this partial equilibrium framework concerns grapes, which are an input to different types of wine plus an input to brandy, which is part of the spirits sector.
} 
Indirect tax collections $\left(T A X_{r}\right)$ from alcohol consumption are a recurring policy issue. $T_{u r}^{c s}$ is the power of the tax by user.

$$
T A X_{r}=\sum_{u} \sum_{c} \sum_{s} P U_{s r}^{c} . X T 1_{r}^{c s} .\left(T_{u r}^{c s}-1\right)
$$

A typical scenario in GLOBAL-BEV keeps aggregate consumption in each region exogenous. Since the set Drink accounts for a small share of aggregate consumption, the income effects that might arise from endogenous aggregate consumption are second order.

Table 4 contains the definition of variables, values and shares concerning margins, market clearing, macro and tax collection equations, followed by the TABLO coding.

Table 4. Definitions of variables, shares and parameters in margins, market clearing and tax collection equations in the GLOBAL-BEV model

\begin{tabular}{ll}
\hline Variables & \\
xtradmar $(\mathrm{c}, \mathrm{r}, \mathrm{d}, \mathrm{m})$ & Margin m on good c going from $\mathrm{r}$ to d \\
xtraddmar $(\mathrm{c}, \mathrm{r}, \mathrm{m})$ & Margin m on good c produced and used in $\mathrm{r}$ \\
atradmar $(\mathrm{c}, \mathrm{r}, \mathrm{d}, \mathrm{m})$ & Tech change: margin m on good c,s going from r to d \\
delTAXint $(\mathrm{c}, \mathrm{s}, \mathrm{i}, \mathrm{r})$ & Ordinary change in intermediate input taxes \\
delTAXhou $(\mathrm{c}, \mathrm{s}, \mathrm{r})$ & Ordinary change in household commodity taxes \\
delhou $(\mathrm{h}, \mathrm{d})$ & Ordinary change in aggregate nominal consumption \\
xstock $(\mathrm{c}, \mathrm{s})$ & Inventories \\
Values, shares and parameters \\
BASSHR $(\mathrm{c}, \mathrm{s}, \mathrm{r}, \mathrm{d})$ & Share of basic value in all-user delivered price \\
MARSHR $(\mathrm{c}, \mathrm{s}, \mathrm{m}, \mathrm{r}, \mathrm{d})$ & Share of margin m in all-user delivered price \\
DELIVRD_R(c,s,r) & Demand in region d for delivered goods from all regions \\
USE $(\mathrm{c}, \mathrm{s}, \mathrm{u}, \mathrm{r})$ & Delivered value of demands: basic + margins \\
USE_U $(\mathrm{c}, \mathrm{s}, \mathrm{r})$ & Total delivered value of regional composite \\
TRADMAR $(\mathrm{c}, \mathrm{s}, \mathrm{m}, \mathrm{r}, \mathrm{d})$ & Margins on trade matrix \\
STOCKS $(\mathrm{c}, \mathrm{s})$ & Domestic inventories \\
\hline
\end{tabular}

Listing 4. Margins (partial GEMPACK coding) in the GLOBAL-BEV model

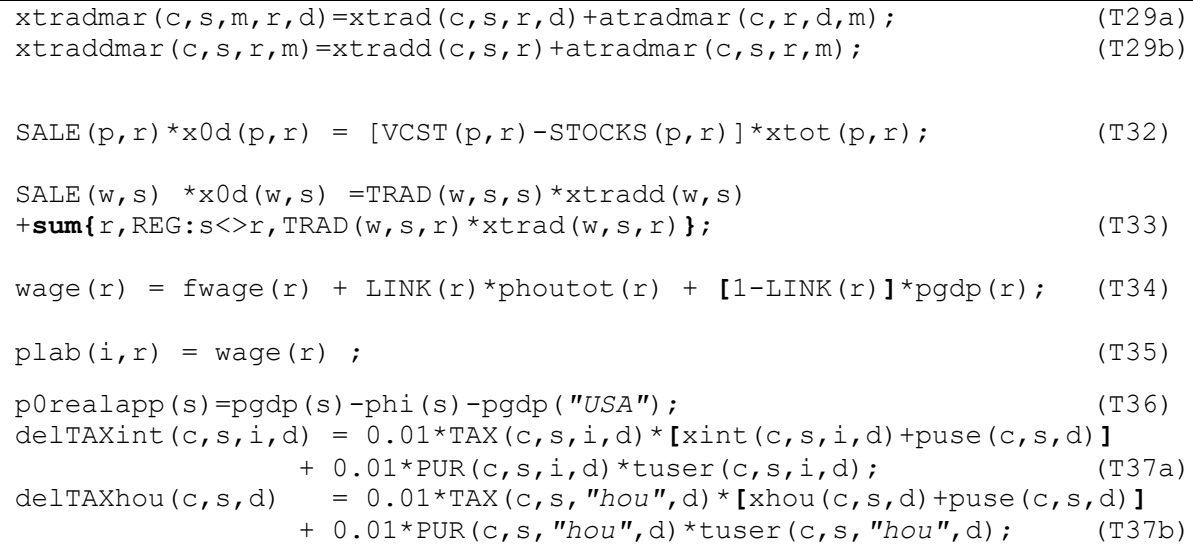




\section{Data sources}

The primary sources of data for constructing the GLOBAL-BEV model's baseline database for 2016-18 are Anderson and Pinilla (2020) plus Anderson (2019) for taxes on beverage consumption and imports, Holmes and Anderson (2017) for wine, beer and spirits average consumer expenditure data, and United Nations (2019) for volume and value of international trade in beverages.

\section{Projecting the GLOBAL-BEV model to 2025 (business-as-usual)}

The model is projected forward to 2025 based on anticipated growth in aggregate national household consumption (a measure of real disposable income) and population together with anticipated changes in real exchange rates that are reported in Appendix Table 1, plus a number of additional assumptions concerning trends in consumer preferences, production, technologies, and capital stocks.

Concerning preferences, there is assumed to be a swing towards all wine types in China, as more Chinese earn middle-class incomes. For the rest of the world, the long trend preference swing away from non-premium wines and toward commercial and superpremium wines is assumed to continue. No changes are assumed for beer and spirits preferences.

Total factor productivity in the grape industry and wine industry is assumed to grow everywhere at $1.2 \%$ and $2.3 \%$ per year, respectively, while grape and wine industry capital is assumed to not grow net of depreciation except in China. However, there is a shift in capital away from non-premium towards premium wine production, in keeping with global demand swings. China's wine production is assumed to rise by one-fifth above its 2016-18 level by 2025, so well above its slumped 2018 level. If China's wine production were to remain at its low 2018 level, its wine imports would increase more than projected below. Total factor productivity is assumed to grow everywhere at $2.3 \%$ per year in the beer and spirits industries.

This global model has supply and demand equations and hence quantities and prices for each of the grape and wine products and for beer and spirits, plus for a single composite of all other products in each country such that it has elements of an economywide CGE model. Grapes are assumed to be not traded internationally, but other products are both exported and imported. Each market is assumed to have cleared before any exogenously introduced shock to the baseline projection of 2025, and to find a new market-clearing outcome following each shock. The inclusion of real exchange rate variables explicitly in the model enables a distinction between price impacts as observed in local currency units from those observed in US dollars. All prices are expressed in real (2017) US dollar terms.

Given the above assumptions, the GLOBAL-BEV model projects Asia will become a substantially larger player in global beverage markets. Specifically, since Asia is currently drinking less wine and beer per capita than the rest of the world, its consumption is expected to keep rising as its economic growth continues; and while its mix of alcohols is now much closer to the world average than it was in earlier decades, the share of grape wine in that mix is still very low. That wine share is projected to increase, just as happened in recent decades in Western European countries that are net importers of wine: only a very small share of the latter's alcohol consumption was accounted for by wine in the early 1960s, but by 2016-18 wine accounted for around one-third of their alcohol consumption. The extent of that preference shift toward wine in Asia is very minor by comparison, with its consumption projected to grow only a little faster for wine than for beer and spirits. As a result, by 2025 
China's shares of global beverage consumption are projected to be 1.7 percentage points higher for wine, 2.7 points higher for beer and 2.1 points higher for spirits than in 2016-18. The shares for the rest of Asia are up too for both wine and spirits, but by less than one percentage point. Africa also is projected to raise its share of global alcohol consumption, but only very slightly. By contrast, shares of Western Europe are projected to be much lower in 2025 than in 2016-18 (Figure 2). Regional shares of world exports do not alter greatly over the projection period, but shares of world imports change non-trivially (see below).

Figure 2. Projected changes in regionala shares of the global volume of consumption of wine, beer and spirits, 2016-18 to 2025 (percentage points)

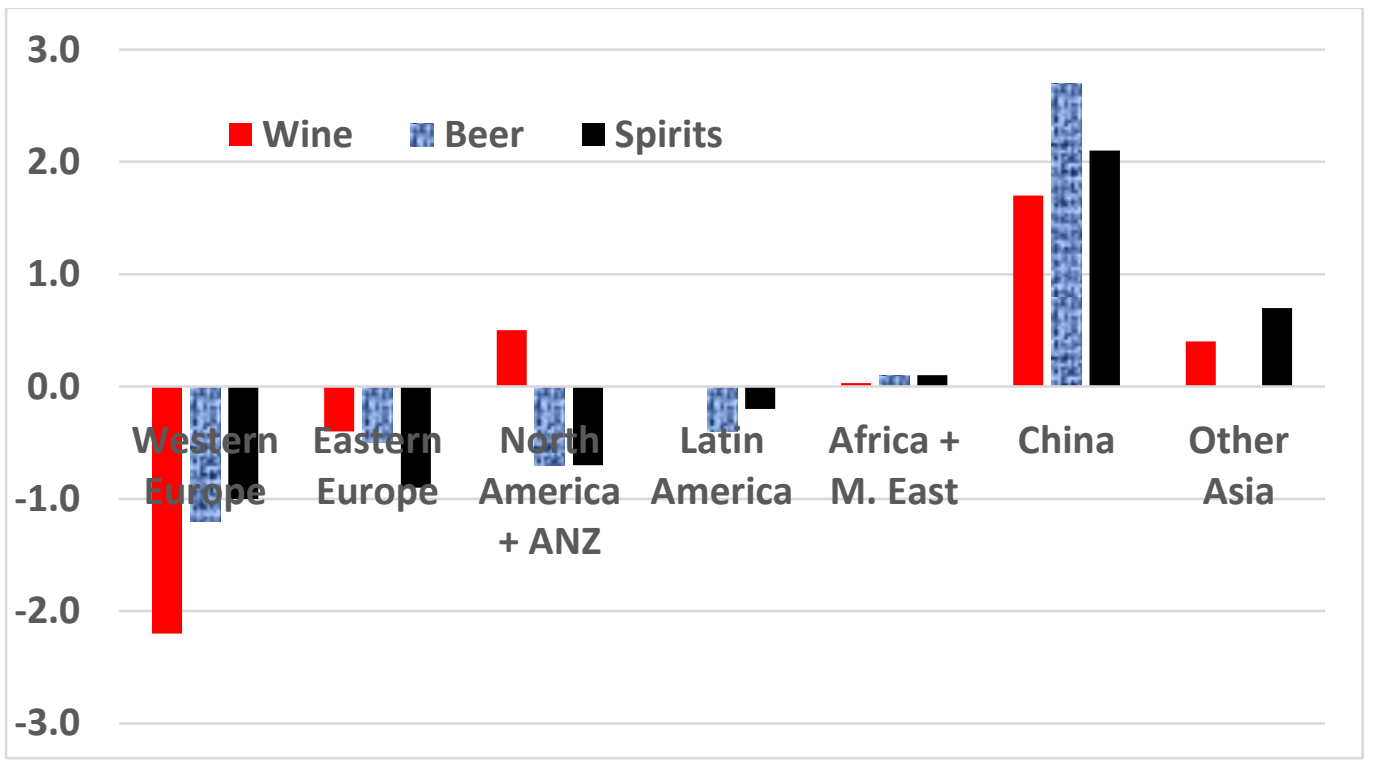

Source: Authors' model projections, business-as-usual.

Given the uncertainty associated with economic growth in developing Asia, we also explore here an alternative, slower-growth scenario to the business-as-usual baseline projection to 2025. It assumes Asia's aggregate household incomes grow only two-thirds as fast as in the baseline rates.

The effect this has on projected changes in the shares of the global value of imports of alcohol are shown in Figure 3. Again China stands out, with its domestic wine production continuing to grow slower than its wine consumption. In the business-as-usual scenario, its share of global wine import value rises by 2.6 percentage points between 2016-18 and 2025, and the rest of Asia's rises by 0.5 percentage points. Africa is the only other region projected to enjoy substantial growth in its share of world wine imports, while Europe is the region whose share is projected to fall, by around 3.4 percentage points for Western Europe and 0.6 percentage points for Eastern Europe. But in the slower-growth scenario in which Asia's economies grow only two-thirds as fast over this period, China's share of global wine imports would rise less than half as much (Figure 3(a)).

The projected changes in the shares of the global value of imports of spirits and beer are shown in Figures 3(b) and 3(c). The overall patterns are similar to that for wine. However, China's growth in importance in global imports increases less for spirits and beer than it does for wine - despite our conservative growth in wine consumption in China over the projection period. In the case of spirits, it is South Asia that dominates projected import growth. 
Figure 3. Projected changes in regional shares of the real value of global wine, spirits and beer imports, 2016-18 to 2025 (percentage points)

(a) Wine imports

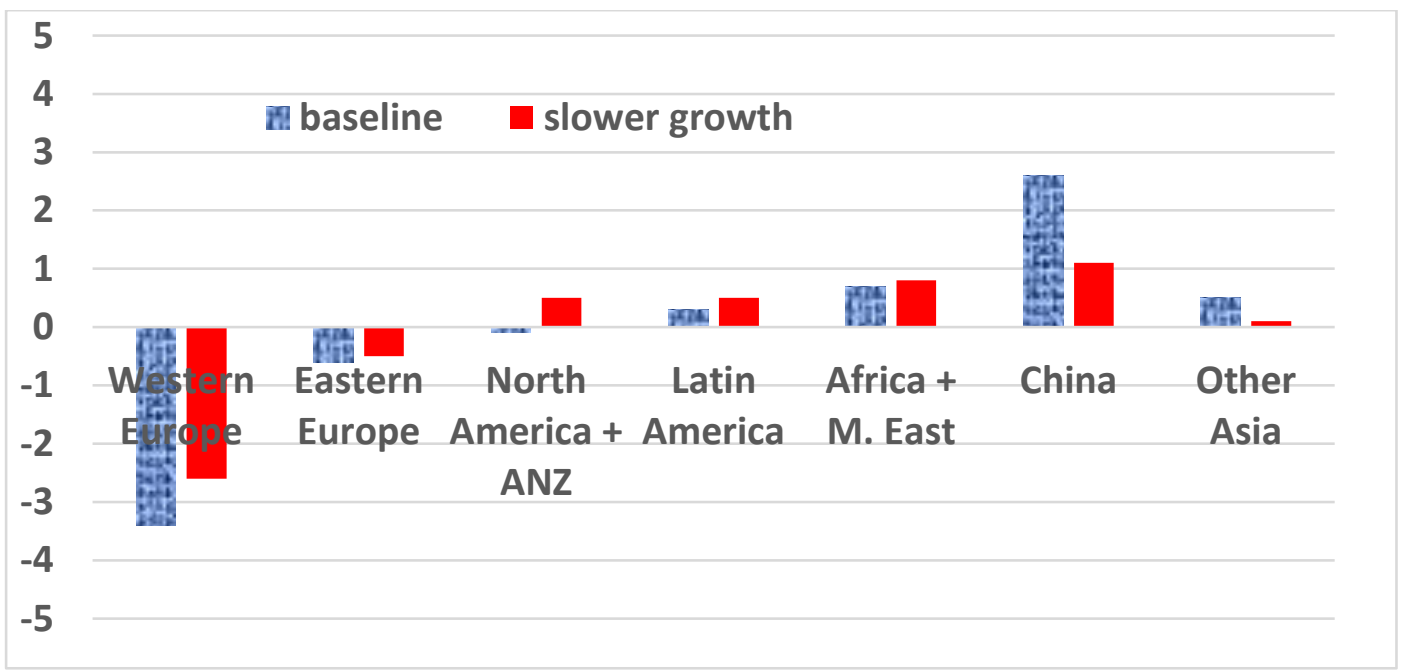

(b) Spirits imports

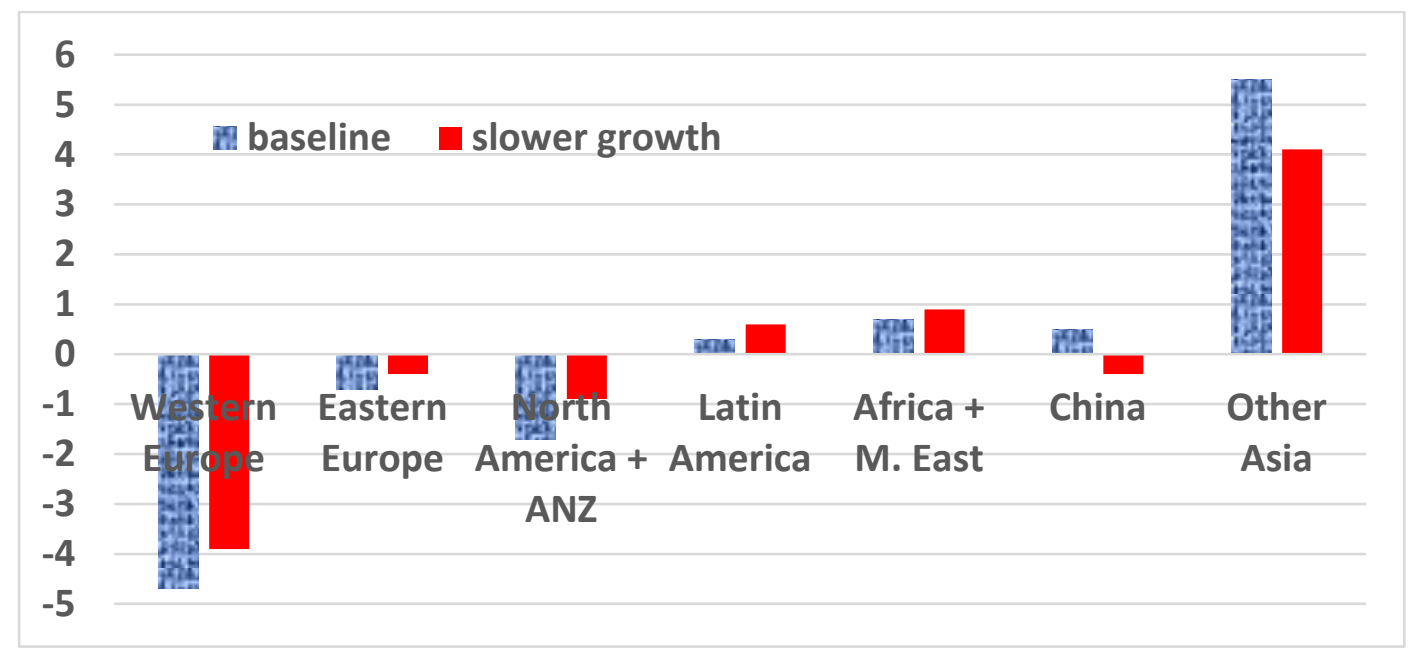

(c) Beer imports

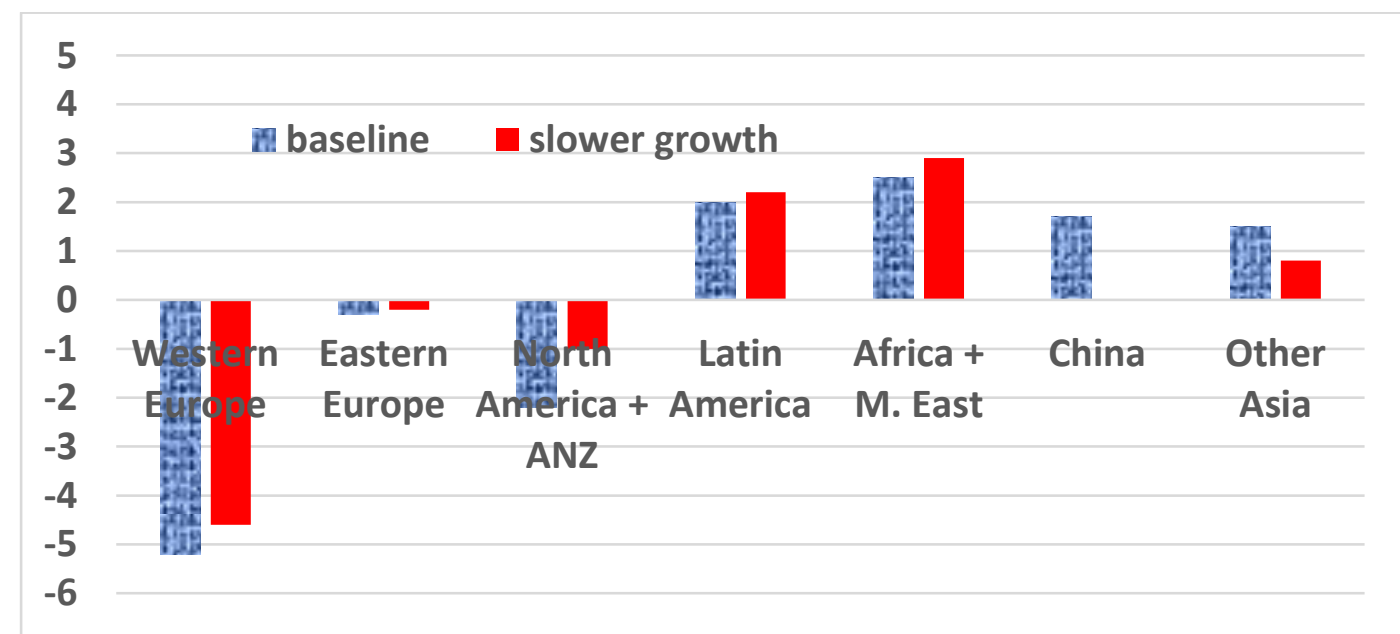

Source: Authors' model projections, business-as-usual and slower Asian growth. 
Were we to have assumed a larger preference swing towards wine relative to beer and spirits consumption in China, that country's importance in global wine imports would have been even higher than that shown in Figure 3(a). That would not have been unreasonable, given that in the above projections shares of alcohol consumption in China alter very little from $4 \%$ for wine, $41 \%$ for beer and $55 \%$ for spirits.

We turn now to two variations on the business-as-usual projection, one showing how Brexit might change global beverage markets by 2025, the other showing the effects on those markets of the extra $25 \%$ tariff on US imports of some EU beverages that President Trump imposed in late 2019.

\section{Effects of Brexit by 2025}

The planned withdrawal of the United Kingdom from the European Union is non-trivial for the world's beverage markets because the UK accounts for nearly $11 \%$ of the world's wine imports, nearly $4 \%$ of global spirits imports and $25 \%$ of global spirits exports in value terms, with half of UK wine imports and two-thirds of UK spirits imports coming from other member countries of the EU. As well, around one-third of UK spirits exports go to other EU member countries.

Brexit has already had a non-trivial impact on markets as the Pound has declined by more than $10 \%$ against all pertinent currencies since the referendum in June 2016, and UK income and household consumption growth have slowed. Moreover, uncertainty over how the UK will exit the EU has reduced business investment in the UK, other EU countries and non-EU trading partners (Bloom et al., 2019; Hassan et al., 2019). The combined effect of these forces already has reduced the UK's demand for imports of most goods, including beverages, compared with what they would have been had the referendum voted for the UK to remain in the EU (Dhingra et al., 2017; Sampson, 2017).

Further effects on beverage markets in the UK and elsewhere will depend on how the UK manages its reforms post-Brexit and whether it achieves a 'hard' or 'soft' exit from the EU. The UK government expects to orchestrate trade deals with numerous non-EU trading partners in addition to the EU in the early part of the current decade, further altering import tariffs and hence bilateral trade flows.

A recent study using the global wine markets model provides projections of the effects of both a 'hard' and a 'soft' Brexit on global wine markets by 2025 (Anderson and Wittwer, 2018). These effects depend not only on assumed changes in the UK's currency and incomes but also on changes in various bilateral tariffs. The study's 'soft Brexit' scenario assumes the UK will negotiate a free trade agreement (FTA) with the remaining 27 EU member countries and then seek bilateral FTAs with others, including wine-exporting Australia, New Zealand, Chile and South Africa. Such trade agreements would reduce the loss to wine exporters across the globe compared with a 'hard' Brexit involving no such follow-on FTA with the EU, but not by enough to offset the adverse effects of the depreciation of the UK's pound and lowered UK incomes.

Here we re-examine the 'soft' Brexit scenario using our new model involving all alcoholic beverages. In this scenarios the rate of UK real GDP growth is assumed to be only two-thirds as fast over the projection period 2017-2025 (1.8\% per year instead of $2.6 \%$ ), and the UK pound is assumed to be $10 \%$ lower in real terms, than in the model's core baseline 'business-as-usual' projection to 2025. It is further assumed the UK applies the EU's external tariffs on beverages imported from non-EU countries at the end of the agreed transition period 
but, because of an assumed new bilateral FTA, trade between the UK and EU27 remains dutyfree.

Table 5 suggests that, because of Brexit, the UK in 2025 would import less beverages from virtually all regions of the world including the EU27, thanks to the UK being less affluent in the first years following Brexit - and despite an FTA with the EU27 in place of the UK being in the EU's Single Market. The UK exports more spirits and beer thanks to declining domestic demand and devaluation of the Pound. However, other countries export less beverages because, since their export prices are now lowered, local sales expand. Their export decline is only partly offset by the UK's export expansion, so global beverage trade declines.

Table 5. Difference in 2025 bilateral wine and spirits import volumes and values from key exporters by the UK and rest of the world (RoW) as a result of a 'soft' Brexit shock (ML and 2014 US\$ million)

(a) wine

\begin{tabular}{lrrrrrr} 
& \multicolumn{3}{c}{ Volume (ML wine) } & \multicolumn{3}{c}{ Value (US\$m) } \\
& UK & RoW & WORLD & UK & RoW & WORLD \\
EU27 & -64 & -17 & -81 & -265 & -63 & -328 \\
Chile & -6 & -2 & -8 & -16 & -6 & -22 \\
South Africa & -2 & -3 & -5 & -4 & -5 & -8 \\
USA & -2 & -2 & -4 & -7 & -8 & -15 \\
Australia & -4 & -3 & -7 & -7 & -11 & -18 \\
Argentina & -5 & -2 & -6 & -19 & -5 & -24 \\
NewZealand & -8 & 4 & -4 & -40 & 19 & -21 \\
Others & -9 & 3 & -6 & -9 & 4 & -6 \\
WORLD & -99 & -21 & -121 & -367 & -75 & -442
\end{tabular}

(b) Spirits

\begin{tabular}{lrrrrrr} 
& \multicolumn{3}{c}{ Volume (ML alc.) } & \multicolumn{3}{c}{ Value (US\$m) } \\
& UK & RoW & WORLD & UK & RoW & WORLD \\
EU27 & -36 & 5 & -31 & -104 & 31 & -72 \\
USA & -1 & -2 & -3 & -7 & -8 & -14 \\
UK & 0 & 25 & 25 & 0 & 96 & 96 \\
Others & -5 & -11 & -16 & -11 & -43 & -54 \\
WORLD & -43 & 17 & -26 & -121 & 75 & -46
\end{tabular}

(c) Beer

\begin{tabular}{lrrrrrr} 
& \multicolumn{3}{c}{ Volume (ML alc.) } & \multicolumn{3}{c}{ Value (US\$m) } \\
& UK & RoW & WORLD & UK & RoW & WORLD \\
EU27 & -35 & -2 & -37 & -82 & -8 & -89 \\
USA & 1 & -3 & -2 & 2 & -7 & -6 \\
UK & 0 & 61 & 61 & 0 & 141 & 141 \\
Others & -11 & -28 & -39 & -26 & -48 & -74 \\
WORLD & -45 & 28 & -17 & -106 & 78 & -28
\end{tabular}

Source: Authors' model results. 


\section{Effects of an extra $25 \%$ tariff on US imports of some EU beverages by 2025}

In October 2019 the World Trade Organization published rulings on a long-running dispute between the United States and the European Union over subsidies to aircraft manufacturing. The rulings allow the US to impose tariffs on annual imports of EU products worth up to US\$7.5 billion. The finding prompted the US to impose tariffs on a wide range of EU goods (USTR, 2019). They include an additional $25 \%$ tariff on still bottled wines with no more than $14 \%$ alcohol from France, Germany, Spain and the United Kingdom, and on Scottish and Irish whiskeys, the aim being to hurt countries that have enjoyed the benefits of EU subsidies to Airbus. Italy and other wine exporters not benefiting from those subsidies were exempted from those new US tariff measures. Champagne and other sparkling wines, high-alcohol (e.g. fortified) wines, and bulk wines in containers greater than two litres, also were exempted, even from the targeted countries.

Such very specific targeting of products that have close substitutes within the beverage group in the targeted countries, and from similar products of other countries, is bound to lead to trade diversion within and across countries. It benefits some firms while hurting others. Some may be able to legally re-label their wines as having, say, $14.5 \%$ alcohol, and thereby avoid the extra tariff. Other firms that import bulk wine from targeted countries and bottle it on arrival in the US will benefit at the expense of competing bottles that continue to be imported directly from those countries. Some US importers or retailers absorbed the tariff hike during the holiday season, but started raising prices from January 2020.

Thus US consumers will face higher beverage prices on average while these additional $25 \%$ tariffs are in place, and so will lower the quantity they buy. Exporters in the targeted countries not only will sell smaller volumes but also will receive lower prices for targeted products, so the value of their exports will fall more than their volume.

But will this boost exports of other countries, and of substitute products of targeted countries? The answer depends on whether the dampening effect of this extra set of taxes on global alcohol consumption more or less than offsets the positive effects through trade diversion on consumption of non-targeted products and countries. Those effects in turn depend on national shares of US wine imports and US shares of national wine exports. These targeted countries in 2017 accounted for two-fifths of the value of US wine imports, and the US accounts for $16 \%$ of global wine imports.

Furthermore, since these new tariffs are percentage rather than volumetric (\$/litre) taxes, they raise the price of affected imported products by more the higher their pre-tax selling price. How important are fine wines in a country's total still bottled wines also matters, therefore. The stronger impact on premium wines means prices of grapes are impacted more in countries exporting mainly high-priced wines. It also means some US consumers shift not just to wines at the lower end of the price range and/or to other beverages, but also to fine wines from non-targeted countries.

Our empirical model of global alcohol markets is able to estimate these potentially diverse effects, especially as it is able to distinguish still wines by quality/price/container size and to separate out sparkling wines. We use it here to estimate the producer price, consumer volume and international trade consequences of these new US tariffs on beverages, focusing on wine because the effects on beer and spirits in this case are much smaller.

\subsection{Producer price and consumer volume effects}


The addition of those selected $25 \%$ tariffs is estimated to raise US prices of winegrapes by an average of $2.6 \%$, and producer prices of bottled still wines by $1.1 \%$. Since sparkling wines are a substitute for still wines, their average price also rises (by $0.2 \%$ ), as does the average price of distilled spirits (by $0.1 \%$ ). Volumes of alcohol consumed in the US therefore drop, the largest fall being by $1.0 \%$ for bottled still wine.

In the targeted countries of France, Germany and Spain (the UK is only a tiny exporter of wine and mostly sparkling), average national winegrape prices are estimated to fall by between $1.3 \%$ and $2.3 \%$, and producer prices of bottled still wines by between $1.3 \%$ and $2.1 \%$. Because of the fall in winegrape prices, non-premium and sparkling wine prices also fall in these countries (by up to $0.2 \%$ ). The volume of domestic consumption of bottled still wines also therefore falls in these countries, by between $0.3 \%$ and $0.7 \%$ in the case of super premium still wines.

In untargeted Italy, by contrast, winegrape prices rise by $1.1 \%$. That helps to raise producer prices of their bottled still wine by $0.7 \%$ and to lower their domestic consumption by $0.2 \%$.

Among the New World countries, the estimated impacts differ according to the importance of the US market to their exports and the quality of the wines they sell in that nowmore-protected market. Australia's average grape price rises by $0.3 \%$ but New Zealand's rises by $1.4 \%$, and the producer price of bottled still wine rises by $0.2 \%$ in Australia and $0.8 \%$ in New Zealand. The reason for the larger price rises in New Zealand than in Australia is because New Zealand's exports to the US account for 33\% of New Zealand's total bottled exports compared with only $19 \%$ for Australia's exports. Also, New Zealand's exports to the US have a higher average unit value than Australia's, and so are a closer substitute for the relatively highly priced EU wines that are now being hit with higher tariffs.

\subsection{Effects on international trade}

The tariffs reduce world trade in wine by $\$ 588$ million per year (a fall of $1.6 \%$ ). Of that total, $\$ 491$ million is the drop in US wine imports (8.1\%). As well, US exports of wine fall by $\$ 185$ million $(11 \%)$ as US consumers substitute away from dearer imported wines in favor of domestic brands.

Most of the net loss in global wine trade (over $\$ 300$ million) is French fine still wine. Spain has a net export loss of \$98 million, while Germany's net export loss amounts to \$19 million per year. These targeted countries reduce their exports to the US by much more than these amounts, but expand their exports to other countries, thereby adding to competition elsewhere for countries such as Australia. Untargeted Italy, by contrast, enjoys a net export increase of $\$ 68$ million, almost all fine wine; and it sells much more to the US but largely at the expense of sales to other countries (Table 6).

Also reported in Table 6 are the impacts of those targeted tariffs on the value of Australian and other New World wine exports net of their imports. As with EU countries, these countries sell much less to the US, because wines there are now more expensive so consumption has fallen, and they sell more to the rest of the world.

However, only three of those five New World countries shown in Table 6 enjoy an increase in their total net exports of wine. As foreshadowed above, even non-targeted countries can be worse off from targeted tariffs if those tariffs reduce global consumption sufficiently. In this case, it appears Australian wine exporters are only slightly better off: they sell US\$96 million more to the US and \$91 million less to other countries such that their export earnings are raised by just $\$ 5$ million per year. New Zealand and Argentina enjoy somewhat 
larger gains, while Chile and South Africa lose slightly. The latter lose because a smaller proportion of their wine exports to the US are fine wines and so they less-easily displace targeted EU fine wines than do Australian, New Zealand and Argentinean exports.

Table 6. Impact of additional US wine import tariffs of $25 \%$ on the value of wine exports net of imports, selected countries (US\$ million per year)

$\begin{array}{lrrrrr} & \begin{array}{r}\text { US share of } \\ \text { national } \\ \text { wine export } \\ \text { value } \%,\end{array} & \begin{array}{r}\text { National } \\ \text { share of US } \\ \text { wine import } \\ \text { value }(\%\end{array} & \begin{array}{r}\text { Estimated } \\ \text { change in net } \\ \text { exports to } \\ \text { the US }\end{array} & \begin{array}{r}\text { Estimated } \\ \text { change in net } \\ \text { exports to rest } \\ \text { of the world }\end{array} & \begin{array}{r}\text { Estimated } \\ \text { change in } \\ \text { total net } \\ \text { exports }\end{array} \\ \text { France } & 16 & 317 & -966 & 640 & -326 \\ \text { Spain } & 16 & 6 & -284 & 186 & -98 \\ \text { Germany } & 17 & 2 & -74 & 56 & -19 \\ \text { Italy } & 26 & 32 & 447 & -379 & 68 \\ \text { Australia } & 18 & 6 & 96 & -91 & 5 \\ \text { New Zealand } & 30 & 7 & 95 & -79 & 16 \\ \text { Argentina } & 35 & 5 & 72 & -41 & 31 \\ \text { Chile } & 14 & 5 & 68 & -70 & -2 \\ \text { South Africa } & 8 & 1 & 20 & -23 & -2 \\ \text { WORLD } & 16 & 100 & & & \end{array}$

Source: Authors' model results.

\section{Conclusion}

The illustrations in the previous sections are just two of many policy scenarios for which the GLOBAL-BEV model is well suited. In addition to trade policy shocks, the model is set up to analyze changes in alcohol consumption taxes. Currently rates of alcohol taxation, and the types of tax instruments used (e.g., volumetric versus ad valorem), vary enormously between countries. Within each country they also vary between beverages, and often between qualities and styles of each beverage (e.g., sparking versus fortified versus still wines). Health lobbies arguing for increases in alcohol taxes have been successful in some countries (Anderson, 2020), and that is encouraging similar pressures in other countries. The GLOBAL-BEV model is ideal for simulating such tax changes, especially in the case of countries that are large importers or exporters of beverages because it is able to capture the likely spillovers to other countries' alcohol markets via international trade.

Competing interests: The authors have no competing interests to declare.

\section{References}

Anderson, K. (2020), "Consumer Taxes on Alcohol: An International Comparison over Time", Journal of Wine Economics 15 (forthcoming).

Anderson, K., G. Meloni and J. Swinnen (2018), “Global Alcohol Markets: Evolving Consumption Patterns, Regulations and Industrial Organizations", Annual Review of Resource Economics 10: 105-32, October. 
Anderson, K., S. Nelgen and V. Pinilla (2017), Global Wine Markets, 1860 to 2016: A Statistical Compendium, Adelaide: University of Adelaide Press. Freely accessible as an e-book at www.adelaide.edu.au/press/titles/global-wine-markets

Anderson, K. and V. Pinilla (2020), Annual Database of Global Wine Markets, 1835 to 2018, Wine Economics Research Centre, University of Adelaide, updated January. www.adelaide.edu.au/wine-econ/databases

Anderson, K., E. Valenzuela and G. Wittwer (2011), "Wine Export Shocks and Wine Tax Reform in Australia: Regional Consequences Using an Economy-wide Approach", Economic Papers 30(3): 386-399.

Anderson, K. and G. Wittwer (2013), "Modeling Global Wine Markets to 2018: Exchange Rates, Taste Changes, and China's Import Growth", Journal of Wine Economics 8(2): 132-58.

Anderson, K. and G. Wittwer (2018), "Cumulative Effects of Brexit and Other UK and EU27 Bilateral FTAs on the World's Wine Markets, The World Economy 41(11): 2883-94, November.

Bloom, N., P. Bunn, S. Chen, P. Mizen, P. Smietanka and G. Thwaites (2019), "The Impact of Brexit on UK Firms", NBER Working Paper 26218, Cambridge MA, September.

Dhingra, S., H. Huang, G. Ottaviano, J.P. Pessoa, T. Sampson and J. Van Reenen (2017), “The Costs and Benefits of Leaving the EU: Trade Effects", Economic Policy 32(92): 651-705, October.

Dixon, P., B. Parmenter, J. Sutton and D. Vincent (1982), ORANI: A Multisectoral Model of the Australian Economy. Contributions to Economic Analysis 142, Amsterdam: North-Holland.

Harrison, J., M. Horridge, M. Jerie and K. Pearson (2014), GEMPACK manual, GEMPACK Software, ISBN 978-1-921654-35-3.

Hassan, T., S. Hollander, L. van Lent and A. Tahoun (2019), "The Global Impact of Brexit Uncertainty", CEPR Discussion Paper 14253, London, December.

Hertel, T. (ed.) (1997), Global Trade Analysis: Modeling and Applications, Cambridge and New York: Cambridge University Press.

Horridge, M. (2011), “The TERM Model and its Data Base”, CoPS Working Paper G-219, July. http://ideas.repec.org/p/cop/wpaper/g-219.html.

Sampson, T. (2017), "Brexit: The Economics of International Disintegration", Journal of Economic Perspectives 31(4): 163-84, Fall.

United Nations (2019) Comtrade Database, accessed 15 August 2019 at https://comtrade.un.org/db/

Wittwer, G., N. Berger and K. Anderson (2003), "A Model of the World's Wine Markets", Economic Modelling 20(3): 487-506. 
Appendix Table 1: Cumulative consumption and population growth rates and changes in the real exchange rate (RER) relative to the US dollar, business-as-usual scenario, 2017 to $2025(\%)$

\begin{tabular}{|c|c|c|c|c|c|c|c|}
\hline & $\begin{array}{r}\text { Aggre } \\
\mathrm{g} \\
\text { consm }\end{array}$ & $\begin{array}{l}\text { Popu- } \\
\text { lation }\end{array}$ & RER & & $\begin{array}{c}\text { Aggreg } \\
\text { consm }\end{array}$ & $\begin{array}{l}\text { Popu- } \\
\text { lation }\end{array}$ & RER \\
\hline France & 16.2 & 3.5 & -4.0 & Australia & 30.8 & 10.1 & -12.8 \\
\hline Italy & 9.7 & 1.3 & -2.1 & New Zealand & 28.1 & 7.6 & -5.0 \\
\hline Portugal & 12.1 & -0.1 & -2.0 & Canada & 23.6 & 7.0 & -3.0 \\
\hline Spain & 23.5 & 6.8 & -1.7 & United States & 27.4 & 7.1 & 0.0 \\
\hline Austria & 17.2 & 3.8 & 0.1 & Argentina & 6.6 & 8.6 & -10.4 \\
\hline Belgium & 17.8 & 6.3 & -1.8 & Brazil & 14.4 & 6.8 & -10.4 \\
\hline Denmark & 19.7 & 2.1 & -2.2 & Chile & 49.0 & 7.2 & -4.1 \\
\hline Finland & 18.9 & 2.9 & 0.4 & Mexico & 37.5 & 10.7 & 0.2 \\
\hline Germany & 12.5 & -1.9 & -4.3 & Uruguay & 40.2 & 2.6 & -7.3 \\
\hline Greece & 19.1 & -0.9 & -7.7 & Other L. Am & 53.2 & 9.2 & -13.6 \\
\hline Ireland & 37.4 & 10.8 & -1.8 & South Africa & 31.9 & 10.2 & 9.5 \\
\hline Netherlands & 18.3 & 3.7 & -2.2 & Turkey & 44.4 & 7.0 & -27.5 \\
\hline Sweden & 21.6 & 7.9 & -6.8 & North Africa & 47.4 & 9.4 & -1.2 \\
\hline Switzerland & 15.6 & 6.7 & -4.5 & Other Africa & 96.4 & 16.2 & 12.5 \\
\hline UK & 28.1 & 4.9 & -1.5 & Middle East & 46.0 & 15.5 & -6.9 \\
\hline Other W.Eur. & 18.6 & 9.2 & -0.3 & China & 70.3 & 3.0 & 3.6 \\
\hline Bulgaria & 36.7 & -6.2 & -1.5 & Hong Kong & 37.4 & 2.3 & -6.4 \\
\hline Croatia & 18.0 & -1.9 & -1.2 & India & 118.8 & 11.5 & 3.0 \\
\hline Georgia & 31.1 & -0.1 & -13.5 & Japan & 10.0 & -2.6 & -0.5 \\
\hline Hungary & 22.6 & -2.7 & -3.7 & Korea & 33.7 & 0.6 & -6.5 \\
\hline Moldova & 43.2 & -10.1 & -10.9 & Malaysia & 55.5 & 13.6 & -8.0 \\
\hline Romania & 39.6 & -3.5 & -4.3 & Philippines & 66.5 & 16.2 & -6.6 \\
\hline Russia & 16.1 & -1.5 & 1.6 & Singapore & 38.8 & 18.6 & -3.7 \\
\hline Ukraine & 19.3 & -4.1 & -5.7 & Taiwan & 26.0 & 1.1 & -5.5 \\
\hline \multirow[t]{2}{*}{ Other E.Eur. } & 35.6 & -4.5 & -10.4 & Thailand & 41.3 & 2.4 & 7.1 \\
\hline & & & & Other Asia & 87.9 & 8.6 & -8.9 \\
\hline
\end{tabular}

Source: Authors' compilation from projections by various international agencies. 